\title{
KONING WILLEM I EN HET EILAND RUATAN \\ DOOR
}

\author{
MR. B. DE GAAY FORTMAN
}

De koloniale archieven uit ons West-Indië bevatten met die van de departementen van koloniën en buitenlandsche zaken nog een schat van gegevens omtrent de plannen van Willem I met ons eilandenbezit beneden den wind in de Caraïbische zee, waarvan de interoceanische verbinding voor Ioo jaar, die de heer Kesler drie jaren geleden stof tot een opstel in dit tijdschrift gaf, een schakel vormde. Bekend is, dat in dien tijd van Nederland uit, maar steeds over Curaçao om den schijn van „buitenlandsche zaken" af te wenden, Zuid- en Midden-Amerika met een corps van handelsagenten en consulaire ambtenaren werd overdekt, die met meer dan één waardevol verslag de belangen van hun land en van hun vorst gediend hebben.

Een dezer consuls was F. J. Travers, die later een belangrijke rol speelde in de internationaalrechtelijke betrekkingen tusschen Nederland en Venezuela, door Mr. Corporaal beschreven. Hij was geplaatst te Truxillo in de toenmalige republiek Centro-Amerika tusschen Mexico en Columbia, omvattende de voormalige Spaansche provinciën Guatemala, San Salvador, Honduras, Nicaragua en Costarica, zijn ambtsgebied was „de baai van Honduras".

Den 26sten Februari 1827 is gedagteekend zijn memorie van aanmerkingen over den staat en de vooruitzichten des handels met de oostkust van het gemeenebest van Centraal Amerika, ingezonden aan den minister van buitenlandsche zaken en in afschrift meegedeeld aan den gouverneur van Curaçao. Daarin bespreekt hij de gun- 
stige voorwaarden, waarop de nieuwe republiek vestiging van vreemdelingen wilde toelaten. Elk tiental familieleden kon een duizendtal acres land krijgen; zij konden zich onder een eigen opperhoofd laten besturen volgens de wetten van hun land, mits niet indruischende tegen de grondbeginselen der republiek. In een noot teekent hij hierbij aan: „Het is niet onwaarschijnlijk, en ik wenschte dat het in de plannen van Zijne Majesteit lag, om door middel van onderhandeling ten deze de aanleiding te vinden, om op die wijze van het eiland Ruatan voor Nederland meester te worden. Eene uitstekende zeehaven, rijke grond en overvloedige voortbrengselen maakten het als dan tot eene benijdenswaardige bezitting in dit gedeelte der waereld"'.

Willem I zou zichzelf niet moeten geweest zijn, wanneer hij niet aanstonds daarop was ingegaan. „Buitenlandsche zaken” en „Koloniën” moesten hun gevoelen zeggen. De inspecteur-generaal, belast met de waarneming der administratie voor de nationale nijverheid, Netscher, stelde de zaak in handen van den oprichter der Maatschappij van weldadigheid J. van den Bosch, die het vraagstuk der kolonisatie ook aan zijn Oost-Indische ervaring kon toetsen. Er was een soortgelijke mededeeling als van Travers ingekomen van den consul in Mexico Grothe. Ten opzichte van beide plannen stond Van den Bosch afwijzend met een beroep op van Imhoffs kolonisatie op Java. Eigenaardig is, dat hij scheen te denken, dat Travers in Columbia zetelde. Hij zou gelegenheid krijgen zich beter op de hoogte te stellen. Wel wees „Buitenlandsche zaken”, wat Ruatan betreft, op art. 21 der te Panama gesloten overeenkomst der Amerikaansche staten, om zich te verzetten tegen de vestiging in hun landen van établissementen zonder vergunning van de gouvernementen, waartoe die gebieden behooren, maar de Koning vond het geraden de zaak nog eens aan Van den Bosch mee te geven op diens West-Indische reis. De kolonisatie-plannen waren van de baan, ofschoon men Travers' opmerking moeilijk anders kan lezen, dan dat hij langs dien weg Ruatan wilde bezetten. 
Van den Bosch zal met dit deel van zijn opdracht gezeten hebben. En toen hij ontdekt had, dat Ruatan niet bij Columbia lag, was er geen bezwaar, de zaak eerst in Suriname weer op te rakelen. Hij vroeg de meening van Cantz'laar, den nieuwen gouverneur-generaal van Nederlandsch West-Indië, die als gouverneur van Curaçao Travers' memorie ontvangen had, maar die wist er ook geen weg mee. Fijntjes antwoordde hij, dat hij altijd gedacht had, dat de briefwisseling tusschen de consulaire ambtenaren en den gouverneur van Curaçao hoofdzakelijk ten doel had de bevordering van den handel van Curaçao, in het bijzonder met de nieuwe gemeenebesten, en om deze reden had hij de stukken over deze zaak achtergelaten in zijn vorige standplaats, zoodat hij niet meer wist, op welke gronden Travers de aanwinst van Ruatan voor Nederland belangrijk achtte. Travers had echter niet veel gronden opgegeven; behalve het reeds genoemde had hij van het eiland een schildering opgegeven als: zeer gezond, overvloed hebbende van allerlei voedsel en voortbrengselen van handel, bijna geheel onbewoond.

Ik zou niet weten, zoo gaat Cantz'laar voort, waarom Ruatan of eenig ander punt op de kust onder de tegenwoordige regeeringen voor den handel met Nederland voordeelig zou kunnen zijn, en Travers zal er nu ook wel zoo overdenken, want een paar maanden geleden schreef hij aan zijn ambtgenoot op Cuba, dat hij wel gauw uit Truxillo de wijk zou moeten nemen, omdat de opstandelingen de overhand hadden gekregen; een plan om alle blanken op kerstnacht te vermoorden was gelukkig voorkomen.

Van Ruatan wist Cantz'laar uit eigen wetenschap ook niets, en hij volstond met aan te halen wat volgens Whittle and Laurie's complete sailing directions for the navigation of the West Indies enz. (Londen 1817) een zekere kapitein Henderson, die het eiland in 1804 had bezocht, meegedeeld had: „Van de zeezijde doet zich dat eiland bijzonder rijk (vruchtbaar) en schoon voor; het is geheel bedekt met boomen, waaronder de cocoboomen de talrijkste zijn; eiken-, pijnboomen en vele anderen van ver- 
scheidene soorten vindt men er mede overvloedig, Rua= tan is aanmerkelijk veel grooter dan velen der West-Indische eilanden, die gecultiveerd zijn; deszelfs grond en de natuurlijke voordeelen, daaraan verbonden, mag mis̄= schien in menig opzigt niet minder bevonden worden dan in eenig derzelven. Daar is overvloed van Rheeền, var= kens, Indiaansche konijnen en vogels van onderscheidene soorten: papegaayen (parokieten) ontelbaar. De Span= jaarden hebben er eene militaire post of kijkuit, hetwelk eerder mag beschouwd worden tot instandhouding van hun regt van bezit door bezetting, dan wel als een middel van verdediging, alzoo die macht slechts uit vijf of zes man bestaat.... De haven van Ruatan, genaamd Port Royal Harbour is aan de Zuidoostzijde van het eiland, en is geformeerd aan de zuidzijde door verscheidene eilandjes en zandbanken, die twee ingangen maken; het grootste dier eilandjes is genaamd Georges' eiland, en het beste kanaal is aan de westzijde daarvan. De Britsche schepen plegen er voormaals hout te halen, en voorzagen zich van water uit een riviertje in het Noordwestelijk gedeelte der haven. De haven is ruim genoeg om 20 à 25 schepen van linie te kunnen bevatten. Vroeger vond men er twee kleine batterijen, een aan de westkant van George's eiland en een ander op een hoogte aan de zuidwestkant der haven. De hoogtens van Ruatan kommandeeren zoo veel uitgestrektheids, dat geen schip naar de baai van Honduras kan stevenen zonder vandaar gezien te worden.

Ruatan is omtrent $7 \frac{1}{2}$ mijl (leagues) lang, nagenoeg in eene oostelijke en westelijke strekking; aan de zuidkust zijn verscheidene kleine haventjes bewesten Port Real, waarvan een onder den naam van Dixons core omstreeks $2 \frac{1}{2}$ mijl (leagues) van de westzijde, hetwelk een geschikte schuilplaats is bij noordenwinden voor schepen, bestemd naar de baay of naar Britsch Yucatan".

Tot zoover Cantz'laars vertaling van Henderson. Daarvoor was het niet noodig geweest de stukken aan Van den Bosch mee te geven. Deze begreep dit ook, en vroeg nadere inlichtingen, maar Cantz'laar bleef het antwoord schuldig, en Van den Bosch wist niet beter te doen, dan bij 
zijn verslag naar de mededeelingen van den gouverneurgeneraal te verwijzen. En zoo kwam de zaak in de doofpot.

Het is maar goed dat Willem I haar verder heeft laten rusten. Een occupatie zou waarschijnlijk op verzet van de Amerikaansche staten, te Panama vergaderd geweest zijnde, en van Engeland gestuit zijn, en dit laatste land zou ook wel tegen de uitvoering van Travers' plan zijn opgekomen. Henderson en Travers beschouwen wel de Spanjaarden en hun opvolgers, de republiek van Centraal-Amerika als eigenaars van het eiland, maar in de October-aflevering $1928 \mathrm{blz} .266$ van dit tijdschrift komt een bericht van Conzemius voor, dat nog in 1797 de Engelschen naar het destijds onbewoonde Ruatan verbanden de twee jaren te voren van St. Vincent naar Balliceaux overgebrachte opstandige Caraïben. Eigenlijk is in de 18de en 19de eeuw de groep der Baai-eilanden, waartoe Ruatan of Roatan behoort, voortdurend een voorwerp van strijd geweest tusschen Engeland eenerzijds en Spanje, de Vereenigde Staten of Honduras anderzijds, een strijd, die eerst in 1859 eindigde met een afstand van Engeland aan Honduras.

Amsterdam 16 Maart 1929. 